Коць Михайло

кандидат психологічних наук, доцент доцент кафедри педагогічної та вікової психології Волинського національного університету імені Лесі Українки https://orcid.org/0000-0002-5607-0564

Ващеня Ганна здобувач першого (бакалаврського) рівня вищої освіти факультету психології та соціології Волинського національного університету імені Лесі Українки https://orcid.org/0000-0002-7034-1500

Кузьмич Олена здобувач першого (бакалаврського) рівня вищої освіти факультету психології та соціології Волинського національного університету імені Лесі Українки https://orcid.org/0000-0003-2644-063X

DOI https://doi.org/10.35619/praprv.v1i16.218

\title{
ГЕНДЕРНІ ОСОБЛИВОСТІ ЕМОЦІЙНОГО ІНТЕЛЕКТУ ДІТЕЙ З ОСОБЛИВИМИ ОСВІТНІМИ ПОТРЕБАМИ
}

Анотація. У статті здійснено теоретичний аналіз та емпіричне дослідження емоційного інтелекту дітей з особливими освітніми потребами.

Зазначається, щзо для успішної соціалізаиії дітей з особливими освітніми потребами одним із ключових чинників є рівень сформованості емочійної сфери. Обтрунтовується важливість того, як за допомогою емоцій і почуттів дитина сприймає навколишній світ $i$ водночас свій внутрішній світ та володіє здібностями емоційного інтелекту як запорукою успішного майбутнього життя.

У результаті емпіричного дослідження гендерних відмінностей емоиійного інтелекту дітей з особливими освітніми потребами встановлено, щэо загальний рівень емочійного інтелекту не характеризується відмінностями між групами вибірки. У хлопців $i$ дівчат переважають показники низьких та середніх рівнів розвитку емоційного інтелекту. Показники внутрішньо-особистісного емоційного інтелекту демонструють, що в більшості хлопців переважає середній його рівень розвитку, а у більшості дівчат - на дуже низькому рівні розвитку. Показники міжособистісного емоційного інтелекту вказують на низький та дуже низький рівень його розвитку, як у більшості дівчат, так і хлопиів.

Гендерні відмінності наявні в структурних компонентах емоційного інтелекту. Так, у вибіриі дівчат переважають здібності до емпатії, здатність управляти емочійними проявами. У вибіриі хлопџів переважають здібності до розуміння свойх емоџій, здатність використовувати емоції в діяльності, керувати чужими емоціями.

Ключові слова: гендерні особливості, емоційний інтелект, діти з особливими освітніми потребами.

Постановка проблеми. Психологічне вивчення емоційного інтелекту є порівняно молодим напрямом, проте в останнє десятиліття концепція емоційного інтелекту стала широко відомою в психології. Емоційний інтелект об'єднує в собі вміння розрізняти і розуміти емоції, керувати власними емоційними станами та емоціями своїх співбесідників. Взаємодія і спілкування між людьми головною мірою залежить від того, як вони сприймають, розуміють, відтворюють та інтерпретують поведінку один одного, оцінюють 
себе та оточення. Відповідно значення емоційного інтелекту полягає у формуванні стосунків у будь-яких умовах для успішної взаємодії в сучасному суспільстві.

Особливу важливість і актуальність розвиток емоційного інтелекту набуває у шкільному віці, оскільки саме в ці періоди відбувається активне емоційне становлення дітей, вдосконалення їх самосвідомості, здатності до рефлексії. У шкільному віці формується емоційне ставлення до світу, цей досвід $\epsilon$ надзвичайно цінним, сприяє емоційному усвідомленню.

Для успішної соціалізації дітей з особливими освітніми потребами одним із ключових чинників $€$ саме рівень сформованості емоційної сфери. За допомогою емоцій і почуттів дитина сприймає навколишній світ і водночас свій внутрішній світ. Емоції спрямовують увагу на важливі події збільшуючи обсяг уявлень, впливають на розумовий процес удосконалюючи мислення, проте не менш важливим є, щоб дитина володіла здібностями емоційного інтелекту, як запорукою успішного майбутнього життя.

Аналіз останніх досліджень 3 проблеми. В останні роки спостерігається підвищений інтерес до вивчення гендерних особливостей емоційного інтелекту. Старший шкільний вік $\epsilon$ сенситивним для формування емоційного інтелекту та характеризується усвідомленням в переосмислені взаємостосунків 3 оточуючими і активною спрямованістю в майбутнє в статусі чоловіка чи жінки, високим рівнем самосвідомості та потребою в самопізнанні.

Специфіка гендеру, як указує Берн (2001), охоплює проблеми статусу, самопочуття, самореалізації чоловіків і жінок у конкретному суспільстві. Гендерні ролі полягають у виявленні гендерної ідентичності особистості, що проявляється в переживанні сукупності суспільних норм и стереотипів поведінки, характерних для представників певної статі (Берн, 2001).

На особливості емоційного інтелекту впливає досить багато чинників, серед яких $є$ гендерні відмінності в прояві компонентів емоційного інтелекту, чиї передумови можуть бути як біологічними, так і соціальними. Відомості про гендерні відмінності емоційного інтелекту є досить суперечливими. Згідно одних досліджень, статеві відмінності в емоційній сфері незначні, згідно з інших, жінки виявляють більш високий рівень 3 міжособистісними показниками емоційного інтелекту, а у чоловіків переважають внутрішньо-особистісні показники, здатності до управління стресом і адаптованість. Згідно поглядів Ільїна (2003), у чоловіків і жінок різний прояв емоцій. Для жінок притаманні сентиментальні почуття, які не характерні для чоловіків, для них швидше характерно проявляти гнів та агресію, що $\epsilon$ непристойним для жінок. (Ільїн, 2003). На думку Дерев'янко (2016), готовність та бажання розповідати про власні переживання є більш характерним для жінок. Реальне емоційне саморозкриття також, в основному, властиво для жінок. Більшість чоловіків намагається уникати розмов про власні переживання з близьким та друзями. При цьому чоловіки часто жалкують про власний відвертість. Поряд із тим, радісні переживання охоче розкривають як жінки, так і чоловіки (Дерев'янко, 2016). Дослідження Гоулман (2019) свідчать, що хлопчики та дівчатка до 10 років суттєво не відрізняються щодо вираження агресивних емоцій. Однак 3 часом дівчата набуваються ефективних умінь у тактиці вербального та невербального виразу емоцій, а хлопчики продовжують виявляти гнів засобами фізичних дій. Це обумовлено впливом сімейного виховання відповідно до гендерних стереотипів: хлопчики мають право на прояв агресії, а дівчатка ні (Гоулман, 2019).

Сформованість емоційно-вольової саморегуляції, як указує Прокопенко, забезпечує особистості здійснення контролю над власною діяльністю і поведінкою, виконаними діями; спрямовує психоемоційну активність відповідно до ситуацій та емоційного наповнення подій 3 метою регулювання міжособистісних стосунків та дотримання соціально значущих правил, норм тощо (2011, с. 193).

Частота переживання основних фундаментальних емоцій майже не залежить від статі. У молодому віці у представників однієї та іншої та жіночої статі однаково переважає радість. На частоту переживання окремий фундаментальних емоцій значний вплив чинить здатність до розуміння та управління емоціями. Так, Андреєва встановила, що у юнаків з підвищенням рівня внутрішньо-особистісного емоційного інтелекту зменшуються переживання провини, 
страху, печалі (2009, с.31-40). Хомська та Батова відзначають, що жінки краще розпізнають емоції тривоги, печалі, задоволення, а чоловіки - гордість, горе, байдужість та ніжність (1998).

Мета дослідження полягає у теоретичному та емпіричному дослідженні гендерних відмінностей емоційного інтелекту дітей з особливими освітніми потребами.

Виклад основного матеріалу дослідження. У дослідженні брали участь учні навчально-реабілітаційного центру. Вибірка досліджуваних складалась з 46 учнів віком від 13 до 17 років. Досліджуваних було розділено на дві групи відповідно до статі респондентів. Перша група складалась 317 дівчат, друга - 29 хлопців.

Для виконання поставлених завдань були використані такі методики: «Діагностика емоційного інтелекту підлітків» (адапт. Садоковою \& Воронковою), методика діагностики емоційного інтелекту (авт. Холл), Тест (опитувальник) емоційного інтелекту (авт. Люсін).

Аналізуючи результати дослідження за методикою «Діагностика емоційного інтелекту підлітків», можна зробити висновки про те, що більша частина вибірки має середній рівень прояву емоційного інтелекту за всіма його компонентам. Усі показники емоційного інтелекту: розуміння своїх емоцій, емпатія, здібності до емоційної регуляції, використання емоцій в діяльності - виражені майже в однаковій мірі (див. табл. 1)

Таблиия 1.

Результати дослідження за методикою «Діагностика емоційного інтелекту підлітків»(адапт. Садокової \& Воронкової)

\begin{tabular}{|l|c|c|c|c|c|c|}
\hline \multirow{2}{*}{ Шкали } & \multicolumn{3}{|c|}{ Кількісні показники наповнюваності рівневих підгруп (у \%) } \\
\cline { 2 - 7 } & \multicolumn{3}{|c|}{ хлопці } & \multicolumn{3}{c|}{ дівчата } \\
\cline { 2 - 7 } & $\begin{array}{l}\text { низький } \\
\text { рівень }\end{array}$ & $\begin{array}{l}\text { середній } \\
\text { рівень }\end{array}$ & $\begin{array}{l}\text { високий } \\
\text { рівень }\end{array}$ & $\begin{array}{l}\text { низький } \\
\text { рівень }\end{array}$ & $\begin{array}{l}\text { середній } \\
\text { рівень }\end{array}$ & $\begin{array}{l}\text { високий } \\
\text { рівень }\end{array}$ \\
\hline $\begin{array}{l}\text { розуміння своїх } \\
\text { емоцій }\end{array}$ & 34 & 45 & 21 & 41 & 29 & 30 \\
\hline емпатія & 10 & 55 & 35 & 35 & 47 & 18 \\
\hline $\begin{array}{l}\text { здібності до } \\
\text { емоційної регуляції }\end{array}$ & 21 & 58 & 21 & 41 & 53 & 6 \\
\hline $\begin{array}{l}\text { використання емоцій } \\
\text { в діяльності }\end{array}$ & 10 & 69 & 21 & 29 & 59 & 12 \\
\hline $\begin{array}{l}\text { загальний показник } \\
\text { емоційного } \\
\text { інтелекту }\end{array}$ & 17 & 69 & 14 & 41 & 47 & 12 \\
\hline
\end{tabular}

Аналіз результатів за шкалами показав наступне. Здібності до розуміння своїх емоцій краще розвинені у хлопців, вони мають значні показники, що відповідають середньому рівню прояву, в дівчат переважає низький рівень прояву. Розуміючи власні емоції особистість здатна краще виражати свої почуття, що сприяє розвиток навичок для успішної взаємодії. Завдяки цьому хлопці більш активні у спілкуванні, їм легко співпрацювати 3 іншими людьми.

Здатність до емпатії представлена як у хлопців, так і в дівчат на однаковому рівні. Навички емпатії допомагають розпізнавати емоційний стан та почуття інших людей i відповідно адекватно сприймати певну ситуацію. Здібностями до емоційної регуляції, а також здатністю до використання емоцій в діяльності на одному і тому ж рівні прояву володіють обидві групи респондентів. Регулятивна функція емоційного інтелекту сприяє стану емоційної комфортності та забезпечує адекватність зовнішнього вираження емоцій людини, дозволяє використовувати інформацію, яку дають емоції, для того, щоб їх викликати або усуватися від них, використовуючи стратегії саморегуляції. Відповідно до 
результатів діти мають здатність справлятися зі своїми негативними переживаннями, або ж здатність мінімізувати інтенсивність або тривалість переживань. Використання емоцій в діяльності дозволяє спрямовувати увагу на важливу інформацію, ухвалення рішень і вибору своєї поведінки. Емоції впливають на розумовий процес і готують до певних дій. Ця здатність допомагає зрозуміти, як використовувати емоції i думати ефективніше. Досліджувані використовують яскраві і доступні емоції, які сприяють розв'язанню певних завдань, що значно розширює погляди на певні події.

Отже, результати дослідження показали, що суттєвих відмінностей між дівчатами та хлопцями у показниках емоційного інтелекту не виявлено. Обидві групи мають середнє значення прояву за загальним показником емоційного інтелекту. Відмінність наявна в компоненті розуміння своїх емоцій, ця здатність краще розвинена в хлопців.

У таблиці 2 представлені кількісні показники, отримані у ході дослідження гендерних відмінностей емоційного інтелекту дітей 3 особливими освітніми потребами, яке здійснювалося за методикою Холла «Діагностика емоційного інтелекту».

Табличя 2

Результати дослідження за методикою "Діагностика емоційного інтелекту»

\begin{tabular}{|l|c|c|c|c|c|c|}
\hline \multirow{2}{*}{ Шкали } & \multicolumn{6}{|c|}{ Кількісні показники наповнюваності рівневих підгруп (у \%) } \\
\cline { 2 - 7 } & \multicolumn{3}{|c|}{ хлопці } & \multicolumn{3}{c|}{ дівчата } \\
\cline { 2 - 7 } & низький & середній & високий & низький & середній & високий \\
\hline емоційна обізнаність & 34 & 34 & 21 & 53 & 35 & 12 \\
\hline $\begin{array}{l}\text { управління своїми } \\
\text { емоціями }\end{array}$ & 65 & 21 & 14 & 30 & 40 & 30 \\
\hline самомотивація & 52 & 28 & 20 & 18 & 47 & 35 \\
\hline емпатія & 45 & 34 & 21 & 30 & 23 & 47 \\
\hline $\begin{array}{l}\text { розпізнавання емоцій } \\
\text { інших людей }\end{array}$ & 44 & 35 & 21 & 53 & 12 & 35 \\
\hline $\begin{array}{l}\text { інтегративний рівень } \\
\text { емоційного інтелекту }\end{array}$ & 60 & 20 & 18 & 41 & 35 & 24 \\
\hline
\end{tabular}

Інтегративний рівень емоційного інтелекту за методикою «Діагностика емоційного інтелекту» (авт. Холл) показує, що в обох групах переважають низькі показники. Це вказує на пригніченість своїми емоціями, низький самоконтроль, низький рівень усвідомленості своїх емоцій.

За результатами про рівні парціального емоційного інтелекту, в першій шкалі «емоційна обізнаність» у хлопців переважає низький та середній рівні розвитку. Це свідчить про певну здатність до об'єктивного оцінювання емоційних проявів. Показники у вибірці дівчат відповідають низькому рівню. Такі люди не в змозі управляти подіями і можуть приймати неправильні рішення, тому що не розуміють себе і своїх емоцій. За шкалою управління своїми емоціями у вибірці хлопців значний відсоток досліджуваних мають низький рівень до цієї здатності. Цей рівень характеризується застряганням на негативно забарвлених переживаннях та емоціях. У результатах дівчат переважає середній рівень розвитку, що свідчить про наявність здатності викликати і підтримувати бажані емоції, тримати під контролем небажані. Згідно результатів за шкалою самомотивація у вибірці дівчат переважає середній рівень розвитку, у вибірці хлопців - низький рівень. Дана здатність зорієнтовує на конкретні дії, спрямовує на пошук ефективних способів вирішення завдань. Емпатія краще розвинена у дівчат, в них переважає високий рівень прояву. Це характеризує їх як здатних до розуміння іншої людини, здатні будувати взаємовідносини 3 іншими людьми. Показники хлопців відповідають низькому рівню прояву. Для людей цього 
рівня характерна байдужість до переживань і думок інших, притаманне зацікавлення на власних думках і почуттях. Показники шкали розпізнавання емоцій інших людей, як у хлопців так і в дівчат переважає низький рівень прояву. Це свідчить проте, що досліджувані не здатні розуміти почуття і наміри інших людей.

Результати дослідження гендерних відмінностей емоційного інтелекту дітей 3 особливими освітніми потребами за шкалами міжособистісного емоційного інтелекту відповідно до методики емоційного інтелекту Люсіна представлені в таблицях 3 та 4.

Таблиия 3

Результати дослідження хлопців за икалами міжсособистісного емоційного інтелекту

\begin{tabular}{|l|c|c|c|c|c|}
\hline \multirow{2}{*}{ Шкали } & \multicolumn{5}{|c|}{ Кількісні показники наповнюваності рівневих підгруп (у \%) } \\
\cline { 2 - 6 } & $\begin{array}{l}\text { дуже } \\
\text { низький }\end{array}$ & низький & середній & високий & $\begin{array}{l}\text { дуже } \\
\text { високий }\end{array}$ \\
\hline $\begin{array}{l}\text { розуміння чужих } \\
\text { емоцій }\end{array}$ & 62 & 18 & 7 & 13 & 0 \\
\hline $\begin{array}{l}\text { управління чужими } \\
\text { емоціями }\end{array}$ & 14 & 45 & 38 & 3 & 0 \\
\hline $\begin{array}{l}\text { міжособистісний } \\
\text { емоційний інтелект }\end{array}$ & 38 & 45 & 14 & 3 & 0 \\
\hline
\end{tabular}

Проаналізувавши отримані результати методики, враховуючи стать респондентів, можна зробити наступні висновки. У обох групах вибірки переважають низькі та дуже низькі показники за шкалами: розуміння чужих емоцій та управління чужими емоціями. Показники міжособистісного емоційного інтелекту також знаходяться на дуже низькому рівні прояву як у дівчат, так і в хлопців. Дуже високий рівень прояву міжособистісного емоційного інтелекту мають тільки дівчата хоч і відсоток досліджуваних значно малий. Проте відсоток хлопців значно менший i iх показники тільки н а високому рівні прояву.

Таблиия 4.

\section{Показники міжособистісного емоційного інтелекту у дівчат} (за методикою Люсіна)

\begin{tabular}{|l|c|c|c|c|c|}
\hline \multirow{2}{*}{ Шкали } & \multicolumn{5}{|c|}{ Кількісні показники наповнюваності рівневих підгруп (у \%) } \\
\cline { 2 - 6 } & $\begin{array}{l}\text { дуже } \\
\text { низький }\end{array}$ & низький & середній & високий & $\begin{array}{l}\text { дуже } \\
\text { високий }\end{array}$ \\
\hline $\begin{array}{l}\text { розуміння чужих } \\
\text { емоцій }\end{array}$ & 29 & 29 & 30 & 0 & 12 \\
\hline $\begin{array}{l}\text { управління чужими } \\
\text { емоціями }\end{array}$ & 40 & 24 & 24 & 12 & 0 \\
\hline $\begin{array}{l}\text { міжособистісний } \\
\text { емоційний інтелект }\end{array}$ & 25 & 24 & 23 & 12 & 6 \\
\hline
\end{tabular}

Низький рівень розвитку усвідомлення почуттів та емоцій інших людей є показником нездатності розуміти почуття і наміри інших людей. Даним досліджуваним важко зрозуміти як поводити себе в тій чи іншій ситуації, вони не в змозі управляти подіями і можуть приймати неправильні рішення.

Аналізуючи результати вивчення гендерних відмінностей емоційного інтелекту дітей 3 особливими освітніми потребами досліджуваних за шкалами внутрішньо-особистісного емоційного інтелекту (тест (опитувальник) емоційного інтелекту Люсіна) (табл. 5, 6) ми отримали наступне. Порівнюючи показники відповідно до шкали розуміння своїх емоцій, виявлено, що у хлопців вони краще розвинуті і відповідають середньому рівню прояву. 
Здатність до розуміння своїх емоцій означає, що людина може розпізнати стан емоційного переживання у себе, встановити, яку саме емоцію переживає і знайти для неї словесне вираження. У більшості з вибірки дівчат діагностується дуже низький рівень розвитку за шкалою розуміння своїх емоцій.

Таблиия 5

Результати дослідження хлопців за икалами внутрішньо-особистісного емоційного інтелекту

\begin{tabular}{|c|c|c|c|c|c|}
\hline \multirow[t]{2}{*}{ Шкали } & \multicolumn{5}{|c|}{$\begin{array}{c}\text { Кількісні показники кожної із рівневих підгруп у } \\
\text { вибірці хлопців (у\%) }\end{array}$} \\
\hline & $\begin{array}{l}\text { дуже } \\
\text { низький }\end{array}$ & $\begin{array}{l}\text { низький } \\
\text { рівень }\end{array}$ & $\begin{array}{l}\text { середній } \\
\text { рівень }\end{array}$ & $\begin{array}{l}\text { високий } \\
\text { рівень }\end{array}$ & $\begin{array}{l}\text { дуже } \\
\text { високий }\end{array}$ \\
\hline розуміння своїх емоцій & 31 & 24 & 35 & 3 & 7 \\
\hline управління своїми емоціями & 7 & 28 & 38 & 20 & 7 \\
\hline контроль експресії & 7 & 17 & 35 & 31 & 10 \\
\hline $\begin{array}{l}\text { внутрішньо-особистісний } \\
\text { емоційний інтелект }\end{array}$ & 10 & 24 & 48 & 11 & 7 \\
\hline
\end{tabular}

Управління своїми емоціями на середньому рівні прояву переважає з вибірки хлопців, у більшості дівчат показники за цією шкалою знаходяться на низькому рівні розвитку. Здатність до управління емоціями означає, що людина може контролювати інтенсивність емоцій, і приглушати досить сильні емоції. Показники свідчать. що хлопці краще контролюють зовнішне вираження емоцій.

Табличя 6

\section{Результати дослідження дівчат за шкалами внутрішньо-особистісного емоційного інтелекту}

\begin{tabular}{|c|c|c|c|c|c|}
\hline \multirow[t]{2}{*}{ Шкали } & \multicolumn{5}{|c|}{$\begin{array}{c}\text { Кількісні показники кожної із рівневих підгруп у вибірці дівчат } \\
(\text { (у\%) }\end{array}$} \\
\hline & дуже низький & низький & середній & високий & дуже високий \\
\hline розуміння своїх емоцій & 46 & 24 & 24 & 6 & 0 \\
\hline $\begin{array}{l}\text { управління своїми } \\
\text { емоціями }\end{array}$ & 29 & 35 & 6 & 0 & 30 \\
\hline контроль експресії & 12 & 24 & 40 & 12 & 12 \\
\hline $\begin{array}{l}\text { внутрішньо- } \\
\text { особистісний } \\
\text { емоційний інтелект }\end{array}$ & 35 & 17 & 24 & 1 & 6 \\
\hline
\end{tabular}

Результати за шкалою контроль експресії свідчать, що у більшості дівчат і хлопців переважає середній рівень розвитку даної здібності. Контроль експресії полягає в здатності контролювати зовнішні прояви своїх емоцій. Ці здібності допомагають стримувати демонстрацію свого переживання, допомагає легше перенести біль або інші неприємні відчуття.

Порівнюючи отримані результати діагностики за методикою емоційного інтелекту Люсіна між групами вибірки, можна зробити висновок, що у більшості як дівчат, так i хлопців, рівень розвитку міжособистісного емоційного інтелекту знаходиться на низькому та дуже низькому рівнях. Такі результати вказують на те, що досліджуваним важко взаємодіяти і налагоджувати взаємостосунки з іншими людьми, їм потрібно розвивати в собі ці здібності. Показники внутрішньо-особистісного емоційного інтелекту демонструють, що в більшості 3 
вибірки хлопців переважає середній рівень розвитку. Хлопці краще володіють собою і впевненіші в собі під час взаємодії з іншими. Показники більшості дівчат знаходяться на дуже низькому рівні розвитку. У дівчат набагато менше впевненості в собі, в них недостатньо виражений самоконтроль над своїми почуттями в конфліктних ситуаціях.

Висновки і перспективи подальших розвідок. У результаті дослідження гендерних відмінностей емоційного інтелекту дітей з особливими освітніми потребами встановлено, що загальний рівень емоційного інтелекту не характеризується відмінностями між групами вибірки. В хлопців і дівчат переважають показники низьких та середніх рівнів розвитку. Показники внутрішньо-особистісного емоційного інтелекту демонструють, що в більшості хлопців переважає середній його рівень розвитку, а у більшості дівчат - на дуже низькому рівні розвитку. Показники міжособистісного емоційного інтелекту вказують на низький та дуже низький рівень його розвитку, як у більшості дівчат, так і хлопців.

Гендерні відмінності наявні в структурних компонентах емоційного інтелекту. Так, у вибірці дівчат переважають здібності до емпатії, здатність управляти емоційними проявами. У вибірці хлопців переважають здібності до розуміння своїх емоцій, здатність використовувати емоції в діяльності, керувати чужими емоціями.

Перспективами подальших розвідок вважаємо розширення засобів діагностики та апробації програм розвитку емоційного інтелекту дітей з особливими освітніми потребами.

\section{СПИСОК ПОСИЛАНЬ}

Андреева, И.Н. (2009). Эмоциональный интеллект как фактор самоактуализации. Социальный и эмоциональный интеллект: от процессов к измерениям. Москва: ИП.

Берн, Ш. (2001). Гендерная психология. Санкт-Петербург: Питер.

Гоулман, Д. (2019). Емоційний інтелект. Харків: Віват.

Дерев'янко, С. П. (2016). Феноменологія емоиійного інтелекту. Чернігів: Десна Поліграф.

Ильин, Е. П. (2003). Дифференцииальная психофизиология мужчины и женщины. СанктПетербург: Питер.

Прокопенко, О. А. (2011). Психологічні особливості розвитку емпатії підлітків з розумовою відсталістю. Вісник післядипломної освіти, 3, 435-440.

Хомская, Е. Д., \& Батова, Н. Я. (1998). Моз и эмоиии. Нейропсихологическое исследование. Москва: Российское педагогическое агенство.

\section{REFERENCES}

Andreyeva, I. N. (2009). Emotsionalnyy intellekt kak faktor samoaktualizatsii. Sotsialnyy $i$ emotsionalnyy intellekt: ot protsessov $k$ izmereniyam. Moskva: IP. [in Russian].

Bern, Sh. (2001). Gendernaya psikhologiya. Sankt-Peterburg: Piter. [in Russian].

Goulman, D. (2019). Emotsiyniy intelekt. Kharkiv: Vivat. [in Ukrainian].

Derev'yanko, S. P. (2016). Fenomenologiya emotsiynogo intelektu. Chernigiv: Desna Poligraf. [in Ukrainian].

Ilin, E. P. (2003). Differentsialnaya psikhofiziologiya muzhchiny i zhenshchiny. Sankt-Peterburg: Piter. [in Russian].

Prokopenko, O. A. (2011). Psikhologichni osoblivosti rozvitku empatii pidlitkiv z rozumovoyu vidstalistyu. Visnik pislyadiplomnoï osviti, 3, 435-440. [in Ukrainian].

Khomskaya, E. D., \& Batova, N. Ya. (1998). Moz i emotsii. Neyropsikhologicheskoye issledovaniye. Moskva: Rossiyskoye pedagogicheskoye agenstvo. [in Russian]. 


\title{
GENDER FEATURES OF EMOTIONAL INTELLIGENCE OF CHILDREN WITH
} SPECIAL EDUCATIONAL NEEDS

\author{
Mykhailo Kots \\ Candidate of Psychological Sciences, Associate Professor \\ Associate Professor of Pedagogical and Age Psychology in \\ Lesya Ukrainka Volyn National University \\ https://orcid.org/0000-0002-5607-0564
}

\begin{abstract}
Anna Vaschenia
applicant of the first (bachelor's) degree Faculty of Psychology and Sociology in Lesya Ukrainka Volyn National University

Olena Kuzmich

applicant of the first (bachelor's) degree Faculty of Psychology and Sociology in Lesya Ukrainka Volyn National University
\end{abstract}

DOI https://doi.org/10.35619/praprv.v1i16.218

\begin{abstract}
The article provides a theoretical analysis and empirical study of emotional intelligence of children with special educational needs.

It is noted that the level of formation of the emotional sphere is one of the key factors for the successful socialization of children with special educational needs. The importance of how with the help of emotions and feelings the child perceives the world around him and at the same time his inner world and possesses the abilities of emotional intelligence as a guarantee of a successful future life is substantiated.

A study of gender differences in the emotional intelligence of children with special educational needs found out that the overall level of emotional intelligence is not characterized by differences between the sample groups. Indicators of low and medium levels of development are dominated among boys and girls. Indicators of interpersonal emotional intelligence show that most of the sample of boys demonstrated medium level of development, and most girls demonstrated very low level of development. The results of interpersonal emotional intelligence are at low and very low levels of development among both girls and boys.

Gender differences are present in the structural components of emotional intelligence. Thus, the ability to empathize and to manage emotional manifestations is dominated among the sample of girls. The sample of boys demonstrated the ability to understand their own emotions, the ability to use emotions in activities, to manage other people's emotions. We consider the expansion of diagnosis means and testing of correctional programs for the development of emotional intelligence of children with special educational needs to be the prospects for further research.
\end{abstract}

Key words: gender features, emotional, children with special educational needs. 